Przegląd Prawa Konstytucyjnego

----ISSN 2082-1212-----

DOI 10.15804/ppk.2018.03.13

-----Nr $3(43) / 2018-----$

\title{
Wspomnienie o Panu Doktorze Arturze Preisnerze
}

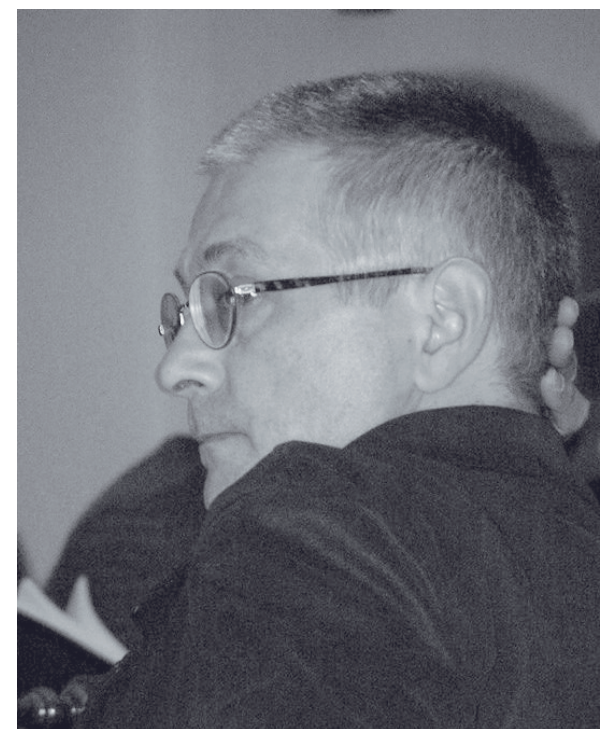

Podobno nie ma ludzi niezastąpionych..., ale są jednak tacy, których jeden człowiek nie zastąpi. Taki właśnie był Artur W. Preisner.

Urodził się we Wrocławiu i właśnie z tym miastem był związany całe swoje życie. Tu uczęszczał do szkół, ukończył studia i został zatrudniony w ówczesnym Zakładzie Prawa Państwowego. To wówczas poznał profesora Kazimierza Działochę, pod którego opieką naukową przygotował rozprawę doktorską poświęconą podziałowi kompetencji ustawodawczych między federację a kraje związkowe w Konstytucji RFN. Warto podkreślić, że znakomitego miał nie tylko promotora, ale i recenzentów w przewodzie doktorskim. Byli nimi profesor Leszek Garlicki z Uniwersytetu Warszawskiego i profesor Paweł Sarnecki z Uniwersytetu Jagiellońskiego. Po obronie dok- 
toratu Artur W. Preisner został zatrudniony na etacie adiunkta w Zakładzie Prawa Państwowego, który w późniejszych latach przekształcił się Katedrę Prawa Konstytucyjnego.

Dorobek naukowy dra Preisnera był zróżnicowany i bogaty, tak jak i bogata była Jego osobowość. Zauważalne było jednak kilka tematów dominujących, pojawiających się od początku Jego kariery akademickiej. Pierwszy nurt to analiza funkcjonowania federalizmu, przede wszystkim niemieckiego, ale - w ograniczonym zakresie - także i szwajcarskiego. Drugim obszarem aktywności naukowej towarzyszącym Mu przez całe życie była problematyka źródeł prawa i najwyższej mocy prawnej Konstytucji RP, w tym także zagadnienie jej bezpośredniego stosowania.

Kolejnym obszarem badawczym, którym zainteresował się dr A.W. Preisner był polski parlamentaryzm, w tym zwłaszcza organizacja i funkcjonowanie Sejmu oraz tematyka procesu ustawodawczego. To pod Jego kierownictwem przygotowana została publikacja - wydawana trzykrotne przez Wydawnict wo Sejmowe pt. Słownik wiedzy o Sejmie. Istotną pracą z tego zakresu było także studium poświęcone sejmowej procedurze ustawodawczej, zatytułowane Pierwsze, drugie i trzecie czytanie (było ono częścią pracy pod redakcją profesora J. Trzcińskiego, Postępowanie ustawodawcze w polskim prawie konstytucyjnym, Warszawa 1994). Po latach, już w odmiennym stanie prawnych dr A.W. Preisner wrócił do tych badań i analizie poddał zagadnienie ogłaszania aktów prawnych (opublikował na ten temat 3 artykuły naukowe, w tym wydany w języku angielskim The promulgation of normative acts: the legal basis and practice, "Globalization, the State and the Individual" 2015, nr 4).

Szczególną rolę w pracy naukowej dra A.W. Preisnera zajmowała tematyka wolności i praw jednostki. Razem z profesorem Bogusławem Banaszakiem był redaktorem fundamentalnej monografii pt. Prawa $i$ wolności obywatelskie w Konstytucji RP, Warszawa 2002 oraz autorem wielu innych publikacji z tego zakresu. Swoistym zwieńczeniem tych rozważań stał się artykuł zatytułowany Paternalizm a wolność, opublikowany w monografii Aktualne wyzwania ochrony wolności i praw jednostki: prace uczniów i wspótpracowników dedykowane Profesorowi Bogusławowi Banaszakowi, pod redakcją Mariusza Jabłońskiego i Sylwii Jarosz-Żukowskiej, Wrocław 2014. 
W ostatnich latach Jego aktywność naukowa związana została $\mathrm{z}$ tematyką nowych technologii i ich wpływem na wolności i prawa jednostki. Podejmował także rozważania na temat wpływu Internetu na współczesną demokrację oraz prowadził badania nad zagadnieniem e-votingu, czyli zasadnością, jak i problemami związanymi z możliwością oddawania głosu w wyborach przy wykorzystaniu urządzeń elektronicznych oraz sieci.

Dr A.W. Preisner uczestniczył także w wielu projektach naukowych, wśród nich także i dwóch największych, kierowanych przez Profesora K. Działochę i obejmujących całe środowisko polskich konstytucjonalistów. Dr A.W. Preisner był w nich - co warto podkreślić - nie tylko współautorem, ale przede wszystkim człowiekiem niezastąpionym, odpowiadającym za ich organizację i realizację.

Oprócz pracy naukowo - badawczej Pan dr A.W. Preisner prowadził także zajęcia dydaktyczne - ćwiczenia, wykłady i seminaria z prawa konstytucyjnego i praw człowieka. Był przy tym niezwykle lubianym dydaktykiem - wyrozumiałym, cierpliwym i bardzo pomagającym seminarzystom w pisaniu pracy dyplomowej. Do końca Swego życia utrzymywał - nawet jeżeli mogło to być już wyłącznie drogą elektroniczną - kontakty ze swoimi studentami.

Swoją bezinteresowną pomoc zawsze okazywał także kolegom i doktorantom z Katedry, a Jego koncepcje można zauważyć w wielu powstałych wówczas pracach naukowych. Był wspaniałym Kolegą, będzie nam Go bardzo brakowało...

opracowanie: Doktor Ryszard Balicki, Profesor Małgorzata Masternak-Kubiak

Pana Doktora Artura Preisnera nie ma już pośród nas, jednak nieustannie pozostaje obecny w pamięci Swych przyjaciól, koleżanek, kolegów oraz studentów. Wyrazem tej obecności są wspomnienia o Doktorze przygotowane przez przedstawicieli nauki prawa konstytucyjnego, osoby, które pozostawały z Nim w bliskich relacjach. Oto niektóre z nich: 


\section{Wspomnienie Profesora Mariusza Jabłońskiego}

Wojtek (Artur) Preisner był barwną postacią. Przez kilkadziesiąt (ponad 20 lat) lat naszej znajomości wielokrotnie i pozytywnie zaskakiwał mnie tak Swoim podejściem do życia, jak i identyfikacją różnego rodzaju zagadnień naukowych. Wojtek był niekonwencjonalny, w tym dobrym słowa znaczeniu, tzn. starał się zidentyfikować problem inaczej niż by to wynikało ze standardowego i utrwalonego (także naukowo) punktu widzenia. Często wydawać się mogło na „pierwszy rzut ucha”, że Jego pogląd jest mocno oderwany od rzeczywistości. Jednak, co zdarzało się dość często - już po niezbyt długim przemyśleniu - okazywało się, że wzięcie pod uwagę innych przesłanek (jak mawiał Wojtek „zmiennych”) prowadzi do oczywistych wniosków tożsamych z tymi, na które wcześniej wskazywał nasz drogi Kolega.

Najciekawsze w tym wszystkim jest to, że Wojtek nigdy nie starał się swojego zdania narzucać, dążył raczej do zaprezentowania rzeczowych argumentów, których siła sama determinowała konieczność uwzględnienia Jego racji. W praktyce umiejętności Wojtka sprawdzały się na każdym zebraniu Katedry Prawa Konstytucyjnego, w szczególności zaś w trakcie analizy różnego rodzaju zagadnień badawczych, $w$ tym również otwieranych przewodów doktorskich. W zasadzie utrwaloną konwencją było to, że po prezentacji meritum zagadnienia jako pierwszy musiał zabrać głos właśnie ON, co w konsekwencji wyznaczało kierunek późniejszej dyskusji.

Jednocześnie Wojtek był człowiekiem, który miał też duży dystans do samego siebie, świetne spojrzenie na różnego rodzaju paradoksy otaczającej nas rzeczywistości tak w odniesieniu do świata polityki, jak i życia codziennego. Potrafił błyskotliwie spuentować konkretne zdarzenia i sytuacje, nie bał się jednocześnie zadawać trudnych pytań, które mogły Go postawić w bardzo kłopotliwej sytuacji. Potrafił też - wtedy, gdy to było potrzebne - w żołnierskich słowach głupotę nazwać głupotą, a bzdurę bzdurą.

Jako obecnemu Kierownikowi Katedry Prawa Konstytucyjnego na Wydziale Prawa, Administracji i Ekonomii Uniwersytetu Wrocławskiego brakuje mi właśnie takiego Wojtka - odważnego, rzeczowego i racjonalnie argumentującego Gościa - który nie boi się powiedzieć co myśli i dlaczego to co mówi ma sens - nawet, jeżeli przeczy to temu, co miał twierdzić Jego „nominalny” zwierzchnik. 


\section{Wspomnienie Profesora Andrzeja Szmyta}

Wczesne lata rozwoju Katedry (wtedy - jeszcze - Zakładu) Prawa Konstytucyjnego i Instytucji Politycznych w gdańskim ośrodku uniwersyteckim - bez samodzielnego pracownika naukowego - sprawiły, że swe losy naukowe mocno związałem z ośrodkiem warszawskim i wrocławskim. Częste kontakty z Katedrą wrocławską przyniosły mi serdeczną współpracę z Arturem Preisnerem - dla mnie zawsze Wojtkiem, z drugiego imienia. Długo łączyła nas problematyka ustroju zachodnioniemieckiego, zanim Wojtek pożeglował ku obszarom badawczym nowych mediów, zwłaszcza Internetu. Mówiąc wprost, tu za Nim nie nadążałem i tak już pozostało. W tradycyjnym obszarze najpierw zdążyliśmy opublikować tekst wspólnego autorstwa o regulacji prawnej procesu legislacyjnego w Republice Federalnej Niemiec („Przegląd Sejmowy” 1944, nr 3), później On był współautorem recenzji mej książki o elementach praktyki ustrojowej w Polsce pod rządami Małej Konstytucji z 1992 r. („Przegląd Sejmowy" 1998, nr 4).

Podziwiałem Jego niespożyte siły i talenty organizacyjne w sferze grantów badawczych, gdzie był katedralnym filarem. Z wzajemnością zawsze mogliśmy na siebie liczyć we współpracy konferencyjnej i wydawniczej. Utkwiły mi w pamięci także liczne nasze rozmowy o idei i koncepcji Słownika wiedzy o Sejmie, zmaterializowanego ostatecznie pod Jego redakcją, rodzącego się m. in. z uwzględnieniem mych wcześniejszych - bez finału - doświadczeń i materiałów z prac podobnego zespołu w Bibliotece Sejmowej.

W mojej pamięci Artur-Wojtek zostanie jako człowiek ciepły, delikatny, zawsze gotów do pomocy.

\section{Wspomnienie Profesora Jerzego Jaskierni}

Doktor Artur Preisner należał niewątpliwie do grona cenionych i lubianych specjalistów prawa konstytucyjnego. Mogłem się o tym przekonać wielokrotnie w trakcie kolejnych Zjazdów Katedr i Zakładów Prawa Konstytucyjnego. Był „duszą towarzystwa”, tryskał humorem, znany był z ciętego języka i dystansu do sporów, jakie toczyły się wśród polskich konstytucjonalistów. 
Ponieważ znany był w naszym środowisku jako „Wojtek” - pod tym imieniem identyfikowane były niejednokrotnie Jego poglądy naukowe. Dotyczyło to m.in. problematyki bezpośredniego stosowania Konstytucji RP. Z charakterystycznym więc dla siebie poczuciem humoru zatytułował swój artykuł poświęcony tej problematyce: Dookoła Wojtek. Jeszcze o bezpośrednim stosowaniu Konstytucji RP, (Sześć lat Konstytucji Rzeczypospolitej Polskiej. Doświadczenia i inspiracje. Profesorowi Kazimierzowi Działosze prace dedykowane na siedemdziesięciolecie urodzin, red. L. Garlicki, A. Szmyt, Warszawa 2003, s. 230 i nast.). Do tego też ma nawiązywać tytuł księgi pamiątkowej poświęconej Arturowi Preisnerowi, którą w 2018 r. ma wydać Uniwersytet Wrocławski.

Nasze drogi życiowe splotły się tylko raz. W 2008 r. otrzymałem propozycję utworzenia w Wyższej Szkole Menedżerskiej w Legnicy, na tamtejszym Wydziale Prawa, Międzynarodowego Centrum Prawa i Zarządzania. Doktor Artur Preisner był tam wówczas zatrudniony jako adiunkt, a ponadto - jeśli dobrze pamiętam - był również dziekanem Wydziału Prawa. Jego pozycja naukowa, doświadczenie dydaktyczne i organizatorskie były tam bardzo wysoko cenione. Miało to dla mnie istotne znaczenie, bo dzięki współpracy z dr. Arturem Preisnerem i kilku znanymi profesorami z obszaru nauk prawnych (m.in. Krystian Complak, Stanisław Kaźmierczyk, Marek Mazurkiewicz) udało nam się utworzyć to Centrum, którego działalność wpisała się nie tylko do dorobku tej uczelni, ale też wniosła wkład do dorobku nauk prawnych szeroko rozumianych. Centrum było m.in. organizatorem międzynarodowych konferencji naukowych: „Rada Europy a przemiany demokratyczne w państwach Europy Środkowej i Wschodniej w latach 1989-2009” (Szklarska Poręba, 2009) oraz „Transformacja systemów wymiaru sprawiedliwości” (Legnica, 2010). Ta ostatnia konferencja zainaugurowana została 10 kwietnia 2010 r. o godz. 9.00, a więc w momencie katastrofy lotniczej w Smoleńsku. Miał ją otworzyć wicemarszałek Sejmu, Jerzy Szmajdziński, który - w odczytanym podczas inauguracji liście usprawiedliwiał nieobecność w związku z udziałem w obchodach 70-lecia zbrodni katyńskiej. Dorobek Centrum jest kontynuowany w postaci międzynarodowych konferencji naukowych dotyczących ochrony praw człowieka, które odbywają się corocznie w Sejmie. 
Okres kontaktów z A. Preisnerem w WSM w Legnicy wspominam jednak nie tylko ze względu na współpracę naukową. Mieliśmy tam okazję, przy „lampce wina”, a niejednokrotnie czegoś mocniejszego, do długich nocnych rozmów o sprawach Polski i Polaków. Mogłem się wówczas przekonać, jak głęboko A. Preisner zaangażowany jest emocjonalnie w przemiany demokratyczne w Polsce i jak przeżywa wszelkie zakłócenia w tym zakresie. Był niewątpliwie człowiekiem wrażliwym, patriotą zaangażowanym w sprawy publiczne. Miał „ciężkie pióro”, ale wszystko to, co napisał, miało swoją wagę. Niejednokrotnie było zaczepne, prowokujące, ale zawsze stanowiło źródło inspiracji do weryfikacji zastanych i utrwalonych, niejednokrotnie bezkrytycznie, poglądów.

\section{Wspomnienie Profesora Stanisława Bożyka}

Ze zmarłym w ubiegłym roku doktorem Arturem Preisnerem spotykałem się niemal corocznie podczas różnych konferencji przez co najmniej 30 lat. Artura poznałem bliżej w ostatniej dekadzie PRL, gdy przygotowywał On rozprawę doktorską o systemie federalnym RFN. Z uwagi na to, że w tamtym okresie sam interesowałem się bliżej problematyką ustroju państw federacyjnych (przede wszystkim Australii), znaleźliśmy wspólny temat do rozmów, czyli zagadnienia struktury i funkcjonowania państw złożonych.

Najbardziej utkwiły mi w pamięci wspólne chwile spędzone w towarzystwie Artura podczas zorganizowanego przez białostocką Katedrę Prawa Konstytucyjnego, kierowaną wówczas przez prof. Eugeniusza Zwierzchowskiego, Zjazdu Katedr w Białowieży w połowie czerwca 1995 r. Szczególnie wieczór w pierwszym dniu Zjazdu, kiedy po powitalnym ognisku w Puszczy Białowieskiej, odbyliśmy niezwykle długie posiedzenie (oczywiście przy kawie, piwie i różnych przekąskach) „połączonych” Katedr konstytucjonalistów z Wrocławia i Białegostoku. Wtedy miałem możliwość przekonać się o licznych zainteresowaniach Artura oraz dowiedzieć się, jak znaczną aktywność przejawiał On na uniwersytecie i poza uczelnią. To nasze ówczesne spotkanie trwało niemal całą noc i zakończyło się niezapomnianym spacerem (przy wschodzącym słońcu), najpierw uliczkami Białowieży, potem zaś obrzeżem budzącej się już do życia puszczy. Mimo praktycznie nieprzespanej nocy, Ar- 
tur oraz pozostali „biesiadnicy” już od godz. 9.00 uczestniczyli w rozpoczynających się obradach Zjazdu. Przede mną zaś było jeszcze, podczas przedpołudniowej sesji, wygłoszenie referatu.

Jeśli się nie mylę, to po raz ostatni spotkałem Artura podczas jubileuszowego Zjazdu Katedr w Gdyni pod koniec kwietnia 2008 r. Z tamtego Zjazdu zapamiętałem chociażby poranną przechadzkę, w towarzystwie Artura i przy szumie fal, promenadą wzdłuż wybrzeża Bałtyku.

\section{Wspomnienie Profesora Jerzego Ciapały}

Ostatnimi czasy tyle wybitnych, znanych i jakoś bliskich mi osób odeszło: Janina Paradowska, Wiktor Osiatyński, Grzegorz Miecugow, Janusz Głowacki. Były to osoby powszechnie znane. Natomiast Artur (Wojtek) był powszechnie znany i bardzo lubiany w naszym środowisku. Inteligencja, kultura, pewna doza ironii powodowały, że Jego wypowiedzi, w tym te na piśmie, były słuchane, czytane i respektowane. Przeczytałem około 15 tekstów Artura, a było ich zdecydowanie znacznie więcej niż moich. Być może powinny być wydane w jakimś zbiorze wspomnień? Pozostaje trudne pytanie: dlaczego tacy ludzie odchodzą tak wcześnie? Sam byłem w 2015 r. na skraju...! Udało mi się. Może za dużo palił? Chyba nie pozostawił przysłowiowej kropki nad swoim dorobkiem, który i tak jest przecież bardzo znaczący. Bywaj, czołem. Pozostaniesz w dobrej pamięci, nie tylko mojej.

\section{Wspomnienie Profesor Anny Młynarskiej-Sobaczewskiej}

Są zapewne ludzie, którzy zmieniają bieg historii. Są też ludzie, którzy mają dar wpływania na innych w szczególny sposób i potrafią dokonać w innych przełomu. Takim człowiekiem był dla mnie Wojtek Preisner. Zresztą z pewnością bardzo by się śmiał z tego nieco pompatycznego początku mojego wspomnienia o Nim, pokrywając w ten sposób zakłopotanie. Bo nie można inaczej zacząć mówić o Wojtku, jeśli się nie wspomni Jego skromności i nieśmiałości. Niemal zawsze był schowany za dymem z papierosa i sarkastycznym uśmiechem, w niezmierzonych odmętach książek i papierów. Zdecydowanie nale- 
żał do tych, których królestwo nie jest z tego świata. Kochał muzykę i literaturę. Czytał ogromne ilości, choć od lat narzekał na wzrok.

Był przy tym bardzo surowym krytykiem. Potrafił być bezlitosny w ocenie („ostatni raz tak niechlujnie zredagowany tekst dostałem do czytania dwadzieścia lat temu z rąk prof. ...”). Ale potrafił włożyć bardzo wiele pracy w to, żeby pomóc innym. Był przy tym także urodzonym polemistą. Wiele rozmawialiśmy o pracy - o Jego książce, która nigdy nie została ukończona - i o mojej książce, która dzięki Niemu w dużej mierze powstała dzięki uwagom Wojtka - bo chociaż poglądy mieliśmy biegunowo odmienne, to właśnie rozmowy z Nim były najbardziej inspirujące. Także dzięki Jego pomocy, bo miał niedościgniony talent do wyszukiwania materiałów i tekstów, a także wielką cierpliwość i ciekawość, która musi cechować naukowca.

Odszedł tak jak żył - po cichu i bez najmniejszej ochoty wywołania rozgłosu. Ale - choć pewnie byłbyś tym szczerze zakłopotany - jeszcze raz Wojtku, dziękuję Ci za wszystkie nasze rozmowy, listy i wspólną pracę.

\section{Wspomnienie Profesora Andrzeja Bisztygi}

Dr Artura Preisnera znałem w zasadzie „od zawsze”, jednoznacznie wiążąc Jego osobę z wrocławską Katedrą Prawa Konstytucyjnego. Był badaczem konstytucyjnym, ale kojarzę Go również z zaangażowaniem w działalność organizacyjną, w tym w działalność wydawniczą Polskiego Towarzystwa Prawa Konstytucyjnego. Artur był naukowcem wyposażonym przez Opatrzność w rzadki dar autentycznie niezależnego i samodzielnego, krytycznego myślenia.

Informacja o śmierci naszego Kolegi, mimo że nie była całkowitym zaskoczeniem, zrobiła na mnie olbrzymie wrażenie. Może dlatego najsilniej w mojej pamięci ujawniło się wówczas nasze ostatnie spotkanie, związane z konsultacjami doktoranckimi odbytymi w Katedrze Prawa Konstytucyjnego we Wrocławiu. Ich przedmiotem były projekty rozpraw doktorskich poświęconych dwóm tematom badawczym, a to: związkom zawodowym jako elementowi konstytucyjnej zasady społeczeństwa obywatelskiego oraz statusowi prawnemu uchodźcy w prawie międzynarodowym, europejskim oraz w porządkach konstytucyjnych wybranych państw. Artur zgłosił wówczas szereg pogłębionych i istotnych dla doktorantów uwag. Posiadał umiejętności szyb- 
kiej orientacji w przedłożonym zagadnieniu oraz prezentacji dobrze uzasadnionej, trafiającej „w punkt” krytyki. Pamiętam Jego wypowiedzi jako oryginalne, zawsze dobrze, ze znajomością rzeczy uzasadnione, wypowiadane w sposób zdecydowany, ale jednocześnie życzliwy, jako że uwagi te już w założeniu podporządkowane były dążeniu do zanalizowania i rozstrzygnięcia zagadnienia badawczego.

Odszedł od nas Dobry Kolega, Człowiek i Naukowiec. Nasze środowisko doznało straty. Arturze, będzie nam Ciebie brakowało.

\section{Wspomnienie Profesora Artura Eawniczaka}

Bohater Opowiastki zbudził się, elegancko ziewnął, ubrał w akademicko dydaktyczny zestaw ubraniowy, po czym podjechał wypasioną w rozsądnych wymiarach taryfą na Wiadomy Fakultet. Szofer zdziwił się co nieco, bo zamiast zwyczajowego: „Proszę nie odjeżdżać, zaraz wracam” Przystojny Pasażer niedbale wyjął wypieszczony banknot i znudzonym głosem wyjaśnił: „Dzisiaj będzie się rozstrzygać bardzo ważna sprawa”!

Następnie dostał się do windy i odbył niespieszną przejażdżkę na Właściwe Piętro, odprowadzany czujnym wzrokiem współtowarzyszy pracy i nauki, taksujących z uznaniem nienaganną pozę i markowe fatałaszki. Zadowolony ze zwyczajowej aprobaty środowiska Pan Doktor zasiadł w Pełnym Europejsko-Bizantyjskiego Splendoru Gabinecie, zapalił co trzeba i zagłębił się w fundamentalnych rozważaniach.

Pojawiła się Rutynowa Koleżanka i z patetycznym przejęciem wypuściła z siebie komunikat: „Kierownik Cię szukał!” Adresat tej dramatycznej wypowiedzi skrzywił się i przenikliwie zawyrokował: „Znowu czegoś chce”. Rozdygotana Protagonistka rozmarzyła się i wyszeptała: „Może szykuje się jakaś potężna zmiana Konstytucji lub Tomiszcze Uczonych w Piśmie i potrzebny jest jakiś Dogłębny Komentator?”

Zanim Renomowany Konstytucjonalista zdołał wyrazić swoje, oparte na genetycznej przenikliwości i wielosezonowym doświadczeniu, powątpiewanie pokazał się Przełożony i zdecydowanie, jak na Wieloletniego Przywódcę przystało, nakazał: „Chodź no Pan!”. Gdy już obaj doświadczeni badacze 
zasiedli w gierkowskich fotelach, ten ważniejszy rutynowo zagadał: „Dajcie zapalić coś dobrego!”

W trakcie rytuału oddawania się ty toniowej komunii reprezentujący najlepsze tradycje roboczego ludu Naczelnik zmierzył przenikliwym spojrzeniem wielkomiejskiego podwładnego i zawyrokował: „Powinniście zapisać się do Partii!” Doktor z przedmieścia zakrztusił się przeznaczonym dla niedobitych burżujów dymem i, wspomniawszy makiawelistyczną lisią ścieżkę, postarał się przybrać opanowany ton, aby sformułować przenikliwie merytoryczną ocenę: „Myślę, że jest tam już dostateczna masa wybitnych postaci”. Zaprawiony w klasowych bojach Dziekan nie zdał się zbyć takim oportunistycznym wykrętem i wyjaśnił: „Zgadza się, ale potrzebujemy osobników, których można by wyciąć w ramach zwalczania kolejnego prawicowego odchylenia". Zmieszczaniały Prawnopaństwowiec puścił kłębek peweksowskiego dymu i odsłonił całą głębię swego politycznego jestestwa: „Uroczyście oświadczam, że byłem, jestem i pozostanę centrowym lawirantem, a poza tym muszę już iść wyprowadzić psa, bo inaczej pogryzie dywan!” „To idź Pan, a za parę miesięcy znowu zrobimy Was sekretarzem komisji rekrutacyjnej za psie pieniądze!"

Doświadczony Dydaktyk zaszedł na chwilę na róg do „Artystów”, żeby nabrać dystansu do zastanawiającej rzeczywistości i wznowić trwające od dwóch lat z Wybitnym Twórcą negocjacje na temat kształtu i wymowy okładki „Zeszytów dla Postępowych Troglodytów”. Po kilku kwadransach owocnych, jak zwykle, obrad Dostojny Uczony wsiadł w MPK i oddalił się łagodnie w stronę zalewanej czasem przez Słowiańską Rzekę Socjalistycznej Sypialni, aby współkonstytuować Podstawową Komórkę Ludowej Ojczyzny, wymienić trafne uwagi z Małżonką, zbadać stan w.w. kobierca, dotlenić podobnego do głowonoga czworonoga, zadumać się nad urojeniami co poniektórych Uczonych w Prawnopaństwowym Piśmie oraz niedbale pomyśleć o czytelnikach „Przeglądu”, którym przyjdzie w udziale czytać takie wspominki - wypominki.

\section{Wspomnienie Profesor Sabiny Grabowskiej}

Wiedziałam, że Artur Preisner, dla wszystkich znajomych - Wojtek, chorował, ale wiadomość o Jego śmierci zupełnie mnie zaskoczyła. Przecież już było lepiej! 
Pamiętam nasze pierwsze spotkanie. Rok 2002 Olsztyn, Zjazd Katedr i Zakładów Prawa Konstytucyjnego. Jak zwykle Zjazd rozpoczynał się grillem. Tam właśnie po raz pierwszy spotkałam Wojtka. On z nazwiskiem w środowisku, ja - tzw. świerzak. A po kilku słowach już rozmawialiśmy jakbyśmy znali się od lat. Niesamowite. Taki był właśnie Wojtek - nie stwarzał dystansu, otwarty, ciepły i z pełnym zrozumieniem dla drugiego osoby.

Był człowiekiem spokojnym, wydawało się, że nic nie wyprowadzi go z równowagi. No chyba, że ktoś zmuszał Go do ubrania garnituru. To był chyba jedyny mankament Wojtka, który już za Jego życia przeszedł do legendy. Znam raptem dwa przypadki, kiedy to Wojtek był widziany z garniturze. Jeden znam tylko z opowiadania. Miało to miejsce na początku Wojtka kariery akademickiej, kiedy to wybrał się na spotkanie do Pana prof. Kazimierza Działochy. A drugi miałam szczęście widzieć osobiście. Było to na Międzynarodowej Konferencji Naukowej nt.: Transformacja systemów wymiaru sprawiedliwości w państwach Europy Środkowej i Wschodniej w latach 1990-2010, która odbyła się w dniach 10-11 kwietnia 2010 r. w Legnicy. Był to widok niesamowity, bo biedny Wojtek stał w holu, nawiasem mówiąc w świetnym garniturze, jak za karę, z nieodłącznym papierosem w ręce i dzielnie znosił wszystkie pytania w typie: Czy to aby na pewno Ty, Wojtku? Czy to jest garnitur? Jeansów Ci zabrakło? Co się stało, żeś ubrał garnitur? Świat się kończy! Wojtek w garniturze! A On tylko powtarzał, że musi dotrwać do oficjalnego otwarcia konferencji, a potem już będzie normalnie ubrany. Bo On wolał nieoficjalne stroje i nieoficjalne rozmowy, takie normalne. Bo Wojtek był właśnie taki normalny. Tej Jego normalności będzie mi brakować najbardziej.

Żegnaj - Antonio Vilfredo Paradontosa y Parapeto!

\section{Wspomnienie Profesor Agnieszki Bień-Kacały}

Szczerze żałuję, że nie miałam okazji poznać kolegi Artura Preisnera bliżej, gdyż bardzo wysoko cenię jego prace naukowe. Spotkaliśmy się jedynie kilka razy na dorocznych Zjazdach Katedr Prawa Konstytucyjnego. Dosłownie też kilka razy mieliśmy okazję porozmawiać, głównie na naukowe tematy. Niewątpliwie były to inspirujące rozmowy. W Arturze bardzo miło zasko- 
czyło mnie jednak Jego niezwykłe poczucie humoru i radość, którą obdarzał wszystkich rozmówców. Szkoda, że tak szybko musiał odejść.

\section{Wspomnienie Doktor Joanny Juchniewicz}

Kiedy dotarła do mnie wiadomość o śmierci Wojtka pomyślałam, że to za wcześnie, że to nie jest właściwy moment na to, by się z nim żegnać. Ale przecież nigdy nie ma dobrego, właściwego momentu na to ostateczne „do zobaczenia”, na to by dalej żyć ze świadomością, że już nigdy nie będzie nam dane się spotkać. Wojtka poznałam na Zjeździe Katedr w Serocku, chociaż jego nazwisko towarzyszyło mi od II roku studiów, kiedy po raz pierwszy sięgnęłam po Prawo konstytucyjne. Wprowadzenie autorstwa Jego i prof. B. Banaszaka.

Pamiętam, kiedy podczas rejsu statkiem po Zalewie Zegrzyńskim ktoś przedstawił mnie Wojtkowi, temu Wojtkowi Preisnerowi z mojego ukochanego Wrocławia, który okazał się być przemiłym, takim trochę po angielsku spokojnym człowiekiem, a do tego z uroczym poczuciem humoru i dystansem do siebie. I z tym angielskim dżentelmenem schodziliśmy ze statku wyposażeni w zestawy plastikowych kieliszków ukryte pod połami marynarki, by dalszą część wieczoru spędzić w towarzystwie przyjaciół konstytucjonalistów i rozgrzewać się w ten chłodny wieczór płynem lanym do tych kieliszków.

Później wielokrotnie spotykaliśmy się na Zjazdach, korespondowaliśmy, Wojtek podsyłał mi książki. Do dnia dzisiejszego mam w skrzynce mailowej wiadomość, którą mi przysłał w odpowiedzi na zaproszenie na III Seminarium Młodych Badaczy Prawa Konstytucyjnego, które organizowaliśmy w Olsztynie - „seminarium młodych... mniemam, że to zwykła pomyłka...” Wojtku, to nie była pomyłka. Pomyłką losu jest to, że Ciebie już z nami nie ma.

\section{Wspomnienie Doktor Anny Frankiewicz-Bodynek}

Doktora Artura Preisnera poznałam w 1997 r., kiedy rozpoczęłam studia doktoranckie w Katedrze Prawa Konstytucyjnego Uniwersytetu Wrocławskiego. Nie chcę tu pisać o Jego osiągnięciach naukowych, bo każdy może przeczy- 
tać Jego publikacje. Chciałabym dać raczej świadectwo tego, jakim był człowiekiem i jak traktował innych.

Z początku postrzegałam Go jako człowieka srogiego - z uwagi na wyraz twarzy i nie znoszącego sprzeciwu - z uwagi na sposób mówienia i ton głosu. Szybko jednak przekonałam się, jak bardzo pozory mogą mylić. Byłam jednym z kilkunastu doktorantów, jacy wówczas robili studia w Katedrze, a pomimo to Doktor Artur Preisner zawsze miał chęć i czas na to, żeby mi pomóc. Pomagał w zasadzie w każdej sferze życia Katedry i robił to w sposób naturalny i niewymuszony. Jeśli widział, że piszę na komputerze - podpowiedział, jak dojść do czegoś w Wordzie krótszą i łatwiejszą drogą. Jeśli widział, że nie ma wolnego gabinetu - udostępnił swój, abym mogła wpisać ocenę studentowi. Jednocześnie nigdy nie odczułam, że oczekuje w zamian jakiejś wdzięczności, a trzeba przyznać, że był rozbrajająco szczery i mówił to, co myśli.

Dzielił się także chętnie swoją wiedzą. Nie pamiętam dokładnie, ale najprawdopodobniej Doktor Artur Preisner sam zaoferował mi pomoc przy przygotowywaniu się do otwarcia przewodu doktorskiego. Czytał i korygował mój plan, pomagał w opracowywaniu autoreferatu. Gdy nurtowały mnie jakieś pytania dotyczące tematu pracy, podpowiadał, co jeszcze powinnam przeczytać, żeby móc gruntowniej rozpatrzyć dane zagadnienie. Zawsze mogłam się do Niego zwrócić z każdym pytaniem. Był przy tym skromny. Pamiętam, że podczas jednej z kilku dyskusji, jakie wówczas toczyliśmy zasłuchałam się w Jego wywody i z podziwem mówię: - Ale Pan ma wiedzę. Pan tak wszystko wie. A On mi odpowiedział: - Ja nie wiem. Ja się nad tym zastanawiam.

Z Doktorem Preisnerem przeszliśmy na „Ty” podczas przyjęcia po obronie doktoratu Dra Ryszarda Balickiego. Odtąd był dla mnie Wojtkiem, tak jak dla pozostałych przyjaciół.

Przekonałam się również, że Wojtek nie należał do osób, u których serdeczny stosunek maleje w miarę upływu czasu, przez który On kogoś nie widzi. Kilka lat po ukończeniu studiów doktoranckich pisałam jakiś tekst i musiałam przeczytać książkę, której Wojtek był współredaktorem. Zadzwoniłam więc do Niego z prośbą o pożyczenie egzemplarza. Oczywiście Wojtek bez zawahania wyraził chęć pomocy. Gdy już trzymałam książkę w ręku, spytałam, do kiedy mam ją zwrócić, a Wojtek powiedział, że mam ją sobie zatrzymać. Do dziś myślę o Nim każdorazowo, kiedy korzystam z tej książki. 
Doktor Artur Preisner odszedł z Naszego grona, nie uczynił tego jednak w sposób ostateczny i definitywny. Pozostały ciepłe wspomnienia, które zachowaliśmy w swej pamięci. To one powodują, że Doktor Artur Preisner na zawsze pozostanie w pamięci swych bliskich, przyjaciół, uczniów i współpracowników.

Doctore, non omnes mortuus! 